\title{
Screening white clover cultivars- for improved nutritive value - development of a method
}

\author{
G.C. WAGHORN and J.R. CARADUS \\ AgResearch Grasslands, Private Bag 11008, Palmerston North
}

\begin{abstract}
A method has been developed which enabled 100 white clover cultivars to be screened and ranked for improved nutritive value. Our objective was to identify cultivars having protein which was relatively insoluble and resistant to rumen degradation. The methods were developed for fresh forages, so that the results were applicable to the grazing animal. The clover was harvested and minced to give a particle size distribution similar to material chewed by ruminants during eating. Crude protein solubility was estimated by measuring nitrogen $(\mathrm{N})$ loss from minced clover incubated in nylon bags in the rumen of a cow. This required the optimal amount of dry matter (DM) and incubation times to be determined, variation between animals to be defined and repeatability of measurements established. Crude protein degradation was measured by incubating minced clover with buffered rumen bacteria in vitro and determining net conversion of plant $\mathrm{N}$ to ammonia $\mathrm{N}$. Nitrogen loss to degradation and solubility_for_the-100-cultivars-were-positively correlated $(r=+0.29 ; P<0.01)$. Six white clover cultivars $w \&$ e identified as having low solubility and slow degradation and five cultivars having high solubility and rapid degradation. Mean values for $\mathrm{N}$ loss from nylon bags after $\mathbf{5 . 5 \mathrm { h }}$ (solubility) for the two groups were 71.7 and $79.8 \%(\mathrm{P}<0.001)$ and net degradation of plant $\mathrm{N}$ to ammonia $\mathrm{N}$ was 20.0 and $29.0 \% \quad(\mathrm{P}<0.001)$ for the respective groups.
\end{abstract}

Keywords: nutritive value, protein, rumen, Trifolium repens

\section{Introduction}

This paper is about developing a method. As with any method development the first priority was to define the objective and as far as possible understand the implications surrounding it. Our objective was to screen 100 cultivars of white clover and to select those which would most benefit ruminant nutrition. This task required a good knowledge of the factors affecting nutritive value, and a knowledge of white clover ingestion, digestion and utilization by ruminants. The chemical composition of white clover is implicit in such an understanding, but plant growth habits and morphology were also important.

This paper outlines the screening procedures and the selection of cultivars most likely to benefit ruminants. The methods were developed with a single cultivar of white clover grown under glass and are applicable to other forages such as grasses, tannin containing legumes and conserved feeds. However, in each instance some of the criteria for optimal nutritive value will differ in accordance with the characteristics of the forage under investigation, and require some modification to the screening process.

\section{Nutritive value of white clover}

White clover (Trifolium repens) contains high concentrations of protein and low concentrations of structural fibre in the dry matter (DM) relative to grasses. White clover is of high nutritive value for both sheep (Ulyatt 1981) and cattle (Cammell et al. 1986),_but_it could be improved if the rapid degradation of protein to ammonia by rumen microbes could be reduced.

The loss of protein to ammonia has two costs for the ruminant. The principal cost is that the loss of protein and amino acids by microbial proteolysis in the rumen reduces the amount of amino acids that are available for absorption from the intestine. Ruminants grazing high quality pastures appear to absorb insufficient amino acids relative to energy, so that productivity is less than optimal (e.g. Hogan 1982). Some of the ammonia released by-proteolysis is incorporated into the rumen microbial biomass, but most is absorbed from the rumen and converted to urea in the liver, for excretion as urinary urea. The cost of urea synthesis is up to $4 \%$ of the metabolisable energy intake (Waghom \& Wolff 1984), and this represents a net loss of energy for production. Furthermore, recent evidence suggests that the conversion of absorbed ammonia to urea may involve an additional catabolism of circulating amino acids, and exacerbate the protein: energy imbalance (Beever 1993).

Protein loss from forage entering the rumen can be associated with protein solubility and degradation. 
Solubility is the movement of proteins released from plant cells during mastication into the fluid phase of the rumen environment. Soluble proteins appear to be more susceptible to degradation by micro-organisms than insoluble proteins associated with plant structural components or precipitated by condensed tannins.

Degradation is the destruction of proteins by microbial proteases resulting in the release of ammonia and leaving the carbon skeleton which may be further degraded to carbon dioxide and volatile fatty acids by the micro-organisms. Proteins differ in the rate and extent to which they are lost to degradation in the rumen, with half lives ranging from about 10 minutes (casein) to several hours (seed albumins). Proteins which are slow to degrade have an increasing probability of escape from the rumen, so that they can be hydrolysed in the intestine enabling the constituent amino acids and peptides to be absorbed by the host.

\section{Screening for nutritive value}

The screening process focused on potential protein losses from clover in the rumen but ignored other aspects of nutritive value including fibre degradation because it does not'appear to limit the intake or nutritive value of white clover. The screening procedures ranked the cultivars on both protein solubility and on protein degradation. Cost constraints required nitrogen to be used as an indicator of protein in the clover.

Clover foliage comprises two fractions of quite different nutritive value: the leaflets are protein rich and of high nutritive value, but petioles are resistant to physical breakdown and have a higher fibre and lower protein content than leaf. Hence the leaf:petiole ratio was determined for each sample to be evaluated, together with total $\mathrm{N}$ to ensure that a selection for slower protein breakdown did not select for a low protein, high fibre plant with a low leaf:petiole ratio.

\section{Preparation and mincing the clover for assays}

Nylon bag (in sacco) incubations are a common method for evaluating and ranking ruminant diets. The procedure is used mainly' for concentrate and manufactured diets, which usually have a high dry matter content. These materials are usually freeze dried and ground through a $1 \mathrm{~mm}$ sieve, then placed in a nylon (or similar) bag suspended in the rumen of a fistulated animal. The bag has a pore size of about 40 pm which allows microbes (principally bacteria) to enter and digest the material, but prevents losses of particulate matter.

Comparisons of this kind (Minson 1993) are straightforward and repeatable, and may be appropriate for grains and some processed diets, but freeze drying and grinding is entirely inappropriate for fresh forages grazed by ruminants. It is important that feeds are evaluated in a form similar to that 'seen' by the digestive system, so that we chose to cut fresh herbage and mince it prior to in vivo and in vitro incubations used in this study.

When sheep eat white clover the forage is broken into small particles which can be measured by wet sieving the swallowed material (Waghom et al. 1989). The partidle-size distribution of swallowed material (DM basis), indicated by sieve aperture size and proportion retained on each sieve, is approximately: $4 \mathrm{~mm}(15 \%)$, $2 \mathrm{~mm}(6 \%), \mathrm{Imm}(5 \%), 0.5 \mathrm{~mm}(6 \%), 0.25 \mathrm{~mm}(8 \%)$ with a further $20 \%$ of particulate DM passing through the $0.25 \mathrm{~mm}$ sieve. About $40 \%$ of clover DM is released from the cells in a soluble form by chewing (Waghorn \& Shelton, 1988; Dellow et al. unpublished).

The screening procedure required a technique be developed which could process $100 \mathrm{~g}$ aliquots of each white clover cultivar to achieve a particle-size distribution similar to that of swallowed material. This was by far the most difficult aspect of method development, but we were aware of hand operated mincers used by parents or grandparents which were robust and likely to achieve the desired results. Unfortunately these (metal) mincers are no longer manufactured, so that newspaper advertisements were used to obtain several mincers which were evaluated for the white clover screening. One mincer mascerated white clover to give particle sizes similar to that achieved by sheep during eating. The distribution (DM retained on sieves with varying aperture sizes) was: $4 \mathrm{~mm}(13 \%)$, $2 \mathrm{~mm}(10 \%), 1 \mathrm{~mm} \cdot(14 \%), 0.5 \mathrm{~mm}(8 \%), 0.25 \mathrm{~mm}$ (6\%). with $3 \%$ of particulate material passing the 0.25 $\mathrm{mm}$ sieve, and $46 \%$ of $\mathrm{DM}$ appearing in a soluble form.

It was also apparant that the mincing technique could affect the distribution of DM between fractions (for example if the mincer 'bound up'), so that one person operated the mincer during both the method development and the evaluation of 100 cultivars. Clover was always cut at the same time of day (1300-1400 h) and held on ice for dissection of a subsample into leaf and petiole fractions and mincing on the following day (0800-1000 h). Typically the clover was about $15 \mathrm{~cm}$ high at cutting, and was removed (scissors) at $1 \mathrm{~cm}$ above ground level. All clovers were grown under glass.

\section{In vivo incubation times}

The nylon bags were about $140 \mathrm{~mm}$ long with a circumference of $100 \mathrm{~mm}$, but some potential space is lost when the opening is tied. Previous experience suggested $50 \mathrm{~g}$ fresh minced forage was excessive in 
terms of both physical limitations and because it is important that all of the material is exposed to a similar amount of microbial activity. Excessive filling may reduce the extent to which clover at the centre of the mass is digested relative to clover adjacent to the bag itself, due to a greater time required for rumen liquor to penetrate the forage mass. Conversely, a very small amount of forage will be. digested rapidly leaving insufficient residues for accurate weighing and analyses.

The extent of digestion is also dependent on the time available for microbes to access the clover. Under normal circumstances white clover DM resides in the rumen for about 6-8 hours and about $60 \%$ of the DM is lost to digestion and absorption. It is important that nylon bag samples are not left in the rumen for an excessive period because very little material will remain, and the evaluation will not be representative of normal digestion in the grazing animal.

A trial was undertaken to determine the optimal amount of minced white clover to be. incubated in nylon bags and the duration of incubation. Twenty, 30 and $40 \mathrm{~g}$ of minced material (wet matter) were incubated for $0,6,11,22$ and $34 \mathrm{~h}$ in duplicate by placing two bundles of twelve bags in the rumen of one cow at $1000 \mathrm{~h}$. Each bundle was held in the rumen digesta mass with an $800 \mathrm{~g}$ weight and the cow was turned out to pasture. Appropriate bags were removed at $1600 \mathrm{~h}$, $2100 \mathrm{~h}$ and at 0800 and $2000 \mathrm{~h}$ the following day, then washed in water until no further colour appeared in the water. The bags (with white clover residues) were dried $\left(48 \mathrm{~h}\right.$ at $\left.60^{\circ} \mathrm{C}\right)$ to determine $\mathrm{DM}$ losses to digestion. Analyses of $\mathrm{N}$ content (plant and bag residues) enabled N'losses tō be calculāted:

Rate of $\mathrm{N}$ and DM losses from bags were similar, and $46-94 \%$ of material disappeared after 6-34 h incubation (Table 1). Bags with $20 \mathrm{~g}$ minced clover had insufficient residue material for accurate sampling and analysis, and 30 or $40 \mathrm{~g}$ were more suitable. Losses of about $60 \%$ were representative of normal rumen digestion so an incubation time of $6 \mathrm{~h}$ seemed to be appropriate.

\section{Variation between cows}

Cows are better suited for nylon bag incubations than sheep because their rumens contain a larger quantity of digesta (40-50 1) than sheep (3.5-4.5 1), enabling more bags to be incubated at one time. However, it was important to determine if there was variation between individual cows, so that evaluations of white clover cultivars could be made without errors arising from cow effects.

Two cows of similar age were used for this comparison. They had been fistulated and grazed
Table 1 Percentage loss of dry matter (DM) and-nitrogen (N) from nylon bags containing 20,30 or $40 \mathrm{~g}$ fresh minced white clover incubated for $0,6,11,22$ and $34 \mathrm{~h}$ in the rumen of a cow.

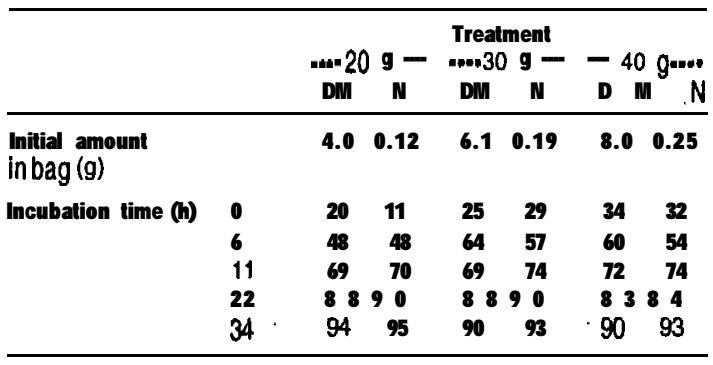

Table 2 Percentage loss of dry matter (DM) and nitrogen (N) from nylon bags containing $30 \mathrm{~g}$ fresh minced white clover incubated in two cows for $0,4,8$ and $12 \mathrm{~h}$. (Data are duplicate measurements).

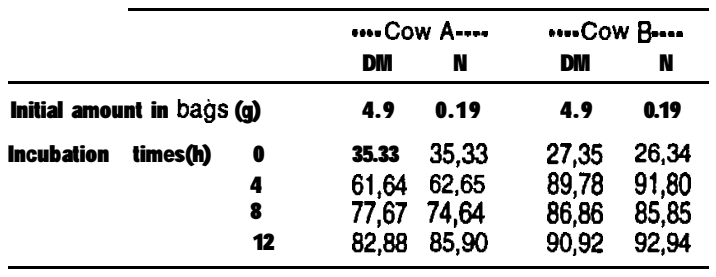

together as part of a small herd for about $\mathbf{8}$ years. Nylon bags containing $30 \mathrm{~g}$ freshly minced white clover were placed in each cow for $0,4,8$ and $12 \mathrm{~h}$ (in duplicate).

After only $4 \mathrm{~h} \mathbf{6 0 - 9 0 \%}$ of the DM had disappeared from the bags. There were large differences between cows in the rate of DM loss, especially between 4 and $8 \mathrm{~h}$ of incubation time (Table 2). Because of the differences between the two individuals, only one animal (Cow A; Table 2) was used to evaluate the 100 white clover cultivars, and an incubation time of $5.5 \mathrm{~h}$ was adopted. DM losses from this comparison may appear to support a shorter, e.g. $4 \mathrm{~h}$, incubation time but errors can arise from a slow -initial inoculation (especially of bags in the middle of the bunde), so that the longer incubation should yield more reliable results.

The differences between cows in rates of DM loss from nylon bags were repeated subsequently. The cows remained grazing together, yet they must have had different microbial populations. These observations have significant implications for forage evaluation using the nylon bag technique, but even greater implications for our understanding of rumen digestion.

It is important that nylon bags be completely immersed in the rumen digesta, and although this is 
facilitated by attaching a weight to the bags it is also important that the bag contents are rapidly wetted with rumen liquor. This can be surprisingly difficult to achieve in a repleat cow fed forage as the rumen contents are frequently tightly packed, so that it is worthwhile removing the cow from pasture for about $10 \mathrm{~h}$ (not more than $16 \mathrm{~h}$ ) before inserting the bags, after which she should be turned out to graze.

\section{In vitro degradation of plant protein}

Nylon bag incubations enable the loss of $\mathrm{N}$ from plant material to be calculated, but there is no indication as to the fate of the lost N. Nitrogen which is solubilised but not degraded is available for intestinal absorption as amino acids and peptides, but solubilised proteins which are degraded to ammonia represent a net loss to the animal (although some will be available when the rumen microbes are digested in the intestines). Because nutritive value is affected by the fate of $\mathrm{N}$ which is lost from plants in the rumen it was necessary to measure the degradation of plant $\mathrm{N}$ to ammonia. Nitrogen degradation was determined by incubating $9 \mathrm{~g}$ minced white clover with $15 \mathrm{ml}$ of mmen liquor (rumen digesta squeezed through cheesecloth) from cow A (Table 2), and $60 \mathrm{ml}$ of buffer to minimise $\mathrm{pH}$ changes over the 8 $\mathrm{h}$ incubation period. In vitro and nylon bag in vivo incubations were conducted simultaneously when the 100 cultivars were screened. The $\mathrm{N}$ content of minced white clover, ammonia content of rumen liquor and the incubation medium after 8 hours were measured and the net conversion of plant $\mathrm{N}$ to ammonia $\mathrm{N}$ was calculated to indicate rates of plant protein degradation. White clover cultivars were ranked on the basis of net ammonia production; those having lowest values probably being the most useful for ruminants.

Throughout the method development and screening, care was taken to avoid dead matter and to monitor plant composition. It was most important to avoid selecting a fibrous plant with a low proportion of leaf.

\section{Evaluation of 100 white clover cultivars}

One hundred cultivars of white clover accessed from Europe, North and South America, Australia and New Zealand (14 cultivars) were grown in trays under glass for evaluation using procedures described here. The initial screening showed that $\mathrm{N}$ losses to degradation and solubility were positively correlated $(r=+0.29$; $\mathrm{P}<0.01$ ) so that high losses from minced clover in the rumen were associated with high rates of protein degradation to ammonia in vitro. After the initial screening (20 cultivars per day plus 2 standards over 5 days), a group of 20 cultivars having slow rates of loss from nylon bags and 10 having high rates of loss from nylon bags were selected for a repeat evaluation in duplicate. The net result was that 6 cultivars were selected as having low rates of solubility and degradation (Bayucua, El Lucera, Nesta, Kopu, California Ladino, Bage) and 5 cultivars having high rates of solubility and degradation (Pastevec, Beta, Sonja, Karina, Smulbladet). Both groups had a similar proportion of leaflet in the DM (35-37\%) but the $\mathrm{N}$ content of the DM (\%) was higher in those having a high $\mathrm{N}$ loss $(4.55 \pm \mathrm{SE}$ $0.074)$ than those having a low $\mathrm{N}$ loss $(4.05 \pm$ SE 0.077 ; P<0.01). Nitrogen losses from nylon bags ( $\%$ of total N) were $71.7 \pm$ SE 1.20 and $79.8 \pm$ SE 0.76 for low and high selections $(\mathrm{P}<0.001)$ whilst in vitro net conversion of $\mathrm{N}$ to ammonia $\mathrm{N}$ were $20.0 \pm \mathrm{SE} 1.01$ and $29.0 \pm \mathrm{SE}$ 1.51 for the respective groups $(\mathrm{P}<0.001)$.

Future work will involve a further evaluation of the thirty cultivars used in the final screening by growing them out of doors and repeating in vitro and in vivo measurements. This will be followed by field trials to establish the extent to which differences in protein solubility and degradation affect the productive performance of sheep and cattle.

\section{Conclusions}

We have developed a method which appears capable of screening fresh white clover cultivars on the basis of crude protein loss to solubility and degradation in the rumen. The optimal method involved mincing freshly cut clover to achieve a distribution of dry matter similar to that when it is chewed during eating. The clover was incubated in nylon bags in the rumen and with buffered rumen liquor in vitro to measure protein solubility and degradation. Nylon bags suspended in the rumen were not allowed to float on the surface. They should not be overfull, and be incubated for 5-6 $\mathrm{h}$ in a single animal. At least 24 bags containing $30 \mathrm{~g}$ wet material can be incubated simultaneously. Calculations of nitrogen loss in vivo must be related to net degradation to ammonia in vitro to determine forages most likely to resist breakdown and loss of plant protein to rumen degradation.

\section{ACKNOWLEDGEMENT}

The authors gratefully acknowledge financial support from the Australian Dairy Research and Development Corporation which made this research possible.

\section{REFERENCES}

Beever, D.E. 1993. Ruminant animal production from forages - present position and future opportunities. 
Proceedings of the XVII International Grassland Congress: 535-542.

Cammell, S.B.; Thomson, D.J.; Beever, D.E.; Haines, M.J.; Dhanoa, MS.; Spooner M.C. 1986. The efficiency of energy utilisation in growing cattle consuming fresh perennial ryegrass (Loliumperenne cv Melle) or white clover (Trifolium repens cv Blanca). British journal of nutrition 55: 669-680.

Hogan, J.P. 1982. In: Nutritional Limits to Animal Production from Pastures: (Ed JB Hacker). Farnham Royal: Commonwealth Agricultural Bureaux.

Minson, D.J. 1993. Prediction of forage digestibility. p. 13 1- 132. In: Forage in ruminant nutrition. Ed. D.J. Minson New York: Academic Press.

Ulyatt, M.J. 1981. The feeding value of herbage: can it be improved? New Zealand agricultural science 15: 200-205.
Waghorn, G.C.; Wolff, J.E. 1984. Theoretical considerations for partitioning nutrients between muscle and adipose tissue. Proceedings of the New Zealand Society of Animal Production 44: 193200.

Waghorn, G.C.; Shelton, I.D. 1988. Red clover composition, 'resistance to shear and effect of maturity when fed to sheep. Proceedings of the Nutrition society of New Zealand 13: 134- 139.

Waghorn, G.C.; Shelton, I.D.; Thomas, V.J. 1989. Particle breakdown and rumen digestion of fresh ryegrass (Lolium perenium) and luceme (Medicago saliva L) fed to cows during a restricted feeding period. British journal of nutrition 61: 409-423. 